Canadian University Music Review

Canadian University Music Review

Revue de musique des universités canadiennes

\title{
Theories of Ethnomusicology and the North American Indian: Retrospective and Critique
}

\section{Wendy Wickwire}

Numéro 6, 1985

URI : https://id.erudit.org/iderudit/1014036ar

DOI : https://doi.org/10.7202/1014036ar

Aller au sommaire du numéro

\section{Éditeur(s)}

Canadian University Music Society / Société de musique des universités canadiennes

\section{ISSN}

0710-0353 (imprimé)

2291-2436 (numérique)

Découvrir la revue

Citer cet article

Wickwire, W. (1985). Theories of Ethnomusicology and the North American Indian: Retrospective and Critique. Canadian University Music Review / Revue de musique des universités canadiennes, (6), 186-221.

https://doi.org/10.7202/1014036ar

(c) Canadian University Music Society / Société de musique des universités canadiennes, 1985
Ce document est protégé par la loi sur le droit d'auteur. L'utilisation des services d'Érudit (y compris la reproduction) est assujettie à sa politique d'utilisation que vous pouvez consulter en ligne.

https://apropos.erudit.org/fr/usagers/politique-dutilisation/ 


\title{
THEORIES OF ETHNOMUSICOLOGY AND THE NORTH AMERICAN INDIAN: RETROSPECTIVE AND CRITIQUE
}

\author{
Wendy Wickwire
}

\begin{abstract}
"When we can give up ethnomusicologizing and spend our time singing and dancing, the maligned word 'progress' may actually have some meaning."
\end{abstract}

(Kenneth Gourlay 1982: 415)

\section{Introduction}

1980 was celebrated as a milestone year in ethnomusicology for it marked the twenty-fifth anniversary of the Society for Ethnomusicology. 1982 could also have been celebrated as a milestone year - the field's centenary - since it was exactly one hundred years earlier, 1882, when the first doctoral dissertation in the field was published. In these milestones, special tribute is due the North American Indian who gave the field a primary studyobject both in early European comparative musicology and later in American ethnomusicology. ${ }^{1}$

It is the object of this paper to evaluate ethnomusicological theory in light of this central figure. The tone throughout is critical, for I argue that ethnomusicologists, despite a century of research, have barely begun to penetrate the identity and ethos of North American Indian music. Indeed, the successive ethnomusicological "schools" have been so conditioned by more general changes in Western perception that a critical historical review of the field reveals more about Western culture and ideology ${ }^{2}$ than about the music and cultures being studied.

The task of reflective critical evaluation is difficult, as the field generally lacks such overviews. Instead, most histories are merely chronological descriptions of the various schools and their 
prominent representatives. ${ }^{3}$ Even these are not well understood, as Alan Merriam noted. "We badly need histories," he wrote in 1969, "particularly histories of ideas, in ethnomusicology, but I do not know of any such activity" (Merriam 1969: 225). Today, almost two decades after Merriam's statement, a thorough history of ethnomusicology still remains to be written (see Nettl 1983: 360). This lack of historical perspective in the field is dangerous, for, as Stanley Diamond has argued for anthropology, we are members of the only civilization which studies and objectifies other societies. How can we study others if we do not also study ourselves? (see Diamond 1969: 402). Stephen Blum, in an article entitled, "Towards A Social History of Musicological Technique" (1975), touches upon such issues. There are, he explains, "contextual variables which determine the epistemology of a musician or scholar." The scholar who explores the creative dimensions of cultures other than his or her own must understand the historical processes for both the societies involved (see ibid.: 208-09). This essay, a history of the North American Indian and the ethnomusicologist, was stimulated by such ideas from Diamond, Blum, and others.

\section{The Renaissance Roots}

Comparative musicology emerged in Europe in the late nineteenth century. Its roots, however, lie deeply buried in the scientific rationalism inherited from the Renaissance. From Copernicus to Newton to Darwin our history is one where everywhere we have organized, systematized, classified, and codified all Nature to try and understand its secrets (see Commager 1977:2). Of the many intellectual problems confronting us, one of the most perplexing is the nature of human identity. For our ancestors who were first exposed to new lands and peoples, the old static concept of a divine social order was deeply shaken. Having encountered the native, some even felt that the natural and universal qualities of mankind were not to be found in the "sophisticated societies of the Old World... [which] were overlaid by customs and traditions, mannerisms and pretentions" but in the new-found lands of the Pacific and of America. This was the noble savage, "man before the Fall, without the taint of artifice, sophistication, and luxury, the social sins and political crimes that corrupt him in the Western world" (ibid.: 73-74). In contrast, the "civilized" man (i.e., European) was one who had thought himself out of a state of nature. Such inquiry was the anthropological context for comparative musicology in its formative state. 
Parallel to this experience of other cultures was a recent transformation in our own. Prior to the 1500s the written word in the West had been a rare sight, secluded instead in the monastery and virtually non-existent as a social medium. Until a couple of hundred years ago, our society's communication was still oral and thus personal, social, and immediate. With a growing dependence upon writing, particularly following the introduction of printing, communication in the West became more highly structured and fixed and hence, more individualistic, less physical and more rational. Literacy and non-literacy themselves were, a century ago, looked upon as respectively, forms of "culture" and "nonculture" (Wynter 1976: 84).

Our society's concept of music was itself much changed during this era. Medieval culture, although stratified in many respects, had been primarily oral, expressive, and participatory, and carried by the people as a whole. In keeping with this, music was generally common to all - a single celebration of community, as art historian Roy McMullen expresses it:

In the high Middle Ages a single aesthetic and single public existed for architecture, sculpture, and painting. Music had more degrees of complexity, but the same modes, rhythms, and even melodies were to be heard in fields, streets, palaces, and churches (1968: 43).

Throughout the Renaissance, music underwent a gradual process of "rationalization" and social stratification, emerging as much more of an art-product of the cultural and political heirarchy of the Court, than an act of participatory community.

A major factor in this rationalization process was the development of a more comprehensive notation system for music. With a stronger adherence to the written score, music assumed a visual quality, that is, something "ultimately reducible to a small finite number of elementary constituents out of which all sounds possibly required in musical praxis can be notated by combining these constituents" (see Wishart 1977: 132). A direct byproduct of notated music was the composer, an individual who had total control over his productions and who could, therefore, produce musical works that could outlive him and become fixtures of high culture. An era of increasing secularization, interest in "celestial music" declined in favor of "musical invention" (Allen 1962: 71). The new wealthy middle class moved in to replace the Church as the patron of the more secular arts. Support for artists and collecting their art became the foundation of high culture. 
Music thus emerged as a more rationalistic and individualistic art form in keeping with other characteristics of the new market society. Some theorists today even draw a direct parallel between the harmonic foundations of post-Renaissance music and the worldview of modern industrial man. John Shepherd, for example, sees tonal harmony, that "hierarchy of fundamentals, all of which ... finally and ultimately relate back to one note" as articulating "the world sense of industrial man," ... "a structure having one central viewpoint" - rationally organized economic production (Shepherd 1977: 105).

Enlightenment thinkers also applied new social theories to music, thereby directly laying the foundations for a comparative musicology. To Jean-Jacques Rousseau, primitive folksongs emanated from natural instincts, in opposition to civilized or conscious art which represented a significantly higher stage of development (see Allen 1962: 306). The wide array and complex design of Western instruments compared with the rugged simplicity of their non-Western counterparts underscored this difference.

While actual contact was still limited, it was possible for the European to romanticize the "primitive" as a vague philosophical ideal. With expanding colonization, however, the "primitive" gradually became a living reality in the European consciousness. His customs, manners, institutions, and beliefs became the subject of an increasingly systematic and well-documented comparative social anthropology. This new branch of study received institutional recognition in 1896 with the appointment of Edward B. Tylor, a social evolutionist, as professor of anthropology at Oxford University.

The development of a systematic study of man was no isolated event but was part of a much larger historical process, a process related to conquest and control. This was a period during which, "for the first time in human history, a small group of peoples now had at their disposal the rest of the peoples and the resources of the earth, due to an initial technological superiority which was to grow by leaps and bounds as wealth accrued from the frontier territories" (Wynter 1976: 82). It is now generally accepted that anthropology helped legitimize or "rationalize" this dominance, for under the banner of the Comparative Method, it sought to demonstrate scientifically that Western European man was superior to large portions of the world (see Burrow 1966). Culture, it was argued, evolved in stages which could be mapped 
chronologically by comparing living primitive peoples to those who had "progressed." Using the culture of European man as the key point-of-reference, the "gold standard of value" (Wynter 1976: 84), the extinction of primitive peoples in the face of colonization could thus be explained scientifically as the natural elimination of the inferior (Harris 1968: 98).

It is important to note here that I am describing general mainstream trends only. Of course there were exceptions to this, in particular, the romantic expressivist tradition which included Jean-Jacques Rousseau and Johann Gottfried Herder, and in early anthropology, individuals such as Bishop Codrington and W. Robertson Smith.

\section{Comparative Musicology Emerges}

Comparative musicology was a direct outgrowth of late nineteenth-century intellectual concerns. Descriptions of native musics from far-away corners of the globe gave rise to many new questions concerning music in general. Encouraged by evolutionary theory, numerous scholors with musicological, psychological, and mathematical interests began to take a serious interest in "primitive" music. Some, who regarded European classical music as an embodiment of high culture, were inspired by Edward Tylor himself, who sought new avenues for anthropological research in the development of "primitive" art. In his pioneering work, Primitive Culture (1958 [1871]), Tylor wrote:

As... [the] arts of civilized life are developed through successive stages of improvement, we may assume that the early development of even savage arts came to pass in a similar way, and thus, finding various stages of an art among the lower races, we may arrange these stages in a series probably representing their actual sequence in history. If any art can be traced back among savage tribes to a rudimentary stage in which its invention does not seem beyond their intellectual condition, and especially if it may be produced by imitating nature or following nature's direct suggestion, there is fair reasons to suppose the very origin of the art to have been reached (1958 [1871]: 63-64).

Before turning to their specific intellectual concerns, it is important to realize that the comparative musicologists were working during what they believed to be a high point in the classical musical tradition. Their music was upheld to be not only "great" music, but also great science. Indeed, the mathematical and 
verifiable content of the rules of classical harmony, partly discovered and partly invented, seemed to give it a prior existence in nature, like that of the contemporary science of elementary particles (see McMullen 1968: 59). With three hundred years of his music preserved on paper, the late nineteenth-century European could look back over time and, like the scientist, view his music in light of new theories of progress and evolution. In the musical world of the nineteenth-century intellectual, the contemplation of the intricacies of the "created product" far outweighed the participatory physical process.

It is against this background that one must see the birth of comparative musicology. The early comparative musicologists believed that a deeper knowledge of their non-European specimens would unravel the mystery of the origins of music in general, and possibly shed light on the pre-history of their own music. With these objectives in mind, numerous monographs were produced, among the more notable, those by Richard Wallaschek (Primitive Music [1970 (1893)], and Carl Stumpf (Die Anfänge der Musik [1911]). Erich M. von Hornbostel, a major figure in this new field of study, disseminated his ideas through a long series of articles rather than a monograph. In one of these, "The Problems of Comparative Musicology," he summarized the overall objectives of this new area of study. We seek, he explained, "to uncover the remotest, darkest past and unveil, in the wealth of the present, the ageless universal in music, ... we want to understand the evolution and common aesthetic foundation of the art of music" (1975 [1905]: 269).

To begin their scientific analysis, comparative musicologists required visual representations of primitive musics. Although an effort was made to transcribe music by ear prior to the development of recording technology, this did not meet with much success. It was only with the assistance of the recording machine in 1889 that unfamiliar sound specimens could be taken into the laboratory and analyzed precisely according to the particular features of their scales and melodies. Early publications in comparative musicology typically consist of a melodic analysis (and, to a lesser extent, a rhythmic analysis) followed by a list of transcriptions.

During this early period, visual concerns heavily out weighed the aural ones. In fact, multiple hearings of original wax-cylinder recordings for the purpose of transcription caused irreparable damage to the recordings, rendering many inaudible. As the 
written version of the recording was considered to be more valuable than the original sound recording, such damage was often treated as a necessary by-product of transcription and, as such, was accepted and often ignored.

The following story recounted by the prominent folklorist, A.L. Lloyd, well illustrates the nature of this preoccupation with transcription. A well-known Hungarian folklorist played a recording of a Csango-Magyar ballad singer from Moldavia for one of his young visitors. The song was particularly poignant and tragic, and the singer "performed it with a fine contained passion, in a way that showed she was totally immersed in the sense of the song." The young visitor was visibly moved by the singer and her song, and the folklorist, upon noticing this, looked at his visitor sternly and advised him: "Surely by now you know that the sound of folk music is meaningless? It's not until we have it down in precise notation and can see what's happening inside the mould of the melody that it comes to have any significance at all" (1970 [1967]: 17-18).

In addition to transcription and analysis, a major activity of comparative musicology was the collection of artifacts - waxcylinder recordings and musical instruments - in archives and museums. For the purpose of filing and cataloguing, systems of classification were developed. Among the more notable of these, that by Erich M. von Hornbostel and Curt Sachs, "Systematik der Musikinstrumente" (1914) is still widely used today. Special phonograph archives were also established for the preservation of sound recordings. The first and foremost of these was the Phonogramm Archives in Berlin, founded in 1900. Six years later it had amassed a collection of approximately one thousand recordings (see Reinhard 1971: 18).

Little attention was directed by many of these early comparative musicologists to the human element in the music, that is, the music-makers. Non-Western singers and musicians were, for the most part, treated much like their Western counterparts as producers of musical specimens. In fact, many comparative musicologists preferred to avoid "the field" altogether. Hence, makers of the music generally remained an unknown. Some were aware that, with increased contact with Western ways their songspecimens were becoming increasingly "contaminated" and even eradicated. The latter fact instilled a sense of urgency into their work, an urgency addressed often not to the destruction of cultures which produced the songs, but to the loss of the song- 
products. Once sufficient specimens were collected, "rationalized," and placed safely in institutions, the disappearance of the culture could proceed apace.

\section{The North American Indian as Study-Object}

From the beginning, the North American Indian provided scholars with a major study-object. In 1882, as mentioned earlier, Theodore Baker completed the first doctoral dissertation on the subject of non-Western music. Undertaken at the University of Leipzig, it was based upon field work among the Seneca Indians of New York and a mixture of native groups at the Carlisle Indian School in Pennsylvania (Baker 1976 [1882]). A few years later, in 1886, Carl Stumpf published an article on Bella Coola Indian music, based on songs which he heard while a group of Bella Coolas was visiting Berlin (Stumpf 1886). In the United States in 1893, Alice Fletcher published a field study of Omaha Indian music (Fletcher and LaFlesche 1893). In all three cases, the songs (as many as ninety-three by Fletcher and forty-three by Baker) were transcribed painstakingly by ear while the singers performed them.

In the early years of the phonograph, the North American Indian continued to serve as a central study-object. The anthropologist J. Walter Fewkes was the pioneer in the use of recording technology. In 1889 he recorded the songs of the Passamaquoddy Indians of Maine (Fewkes 1890a), and the Zunis of New Mexico (Fewkes 1890b). Two years later in 1892, Carl Stumpf used recorded Indian songs to produce what is considered to be the first "precise" analysis of non-Western music, "Phonographierte Indianermelodien" (Stumpf 1892). From this point on, numerous articles appeared, one of the more notable by von Hornbostel and Otto Abraham, an article on forty-four songs of the Interior Salish Indians of British Columbia collected by Franz Boas in 1897 (Abraham and von Hornbostel 1975 [1906]). The prominence of the North American Indian is not surprising, given that during this early period of anthropological investigation, they happened to be amongst the most easily accessible of any primitive peoples, especially as most at this time were living on reservations.

\section{Franz Boas and a New Concept of Culture}

Comparative musicology in America proceeded along a much different course than its European counterpart, due primarily to 
the efforts of Franz Boas. Under Boas all facets of anthropological investigation were infused with a new theoretical and methodological orientation, which laid the groundwork for the field as it is known today.

Although his initial training was in Europe in physics and geography, Boas emigrated to America in the mid-1880s where he quite literally stepped out of the academy into a living and diverse field (see Boas 1887). As his first-hand experience with native peoples broadened, he found it more and more difficult to accept the prevailing social theories. Challenging the notion of civilization as the pinnacle of a single evolutionary phenomenon, Boas argued that an individual culture had to be understood in its own historical context. He attacked the Comparative Method for attempting to order contemporary cultures in a verifiable evolutionary sequence and favoured instead the concept of a plurality of historically-conditioned cultures. Parallels between cultures, he argued, might arise in a multitude of ways.

With the evolutionists in mind, Boas criticized deductive theorizing on the basis of sparse evidence and opposed simplistic models of biological determinism and ethnocentric standards of cultural evolution (Boas 1940: 270-80). A major goal in all this was to eradicate racism and to dispel the notion of the superiority of Western society and its assured scientific rights to exploit other races (see Becker 1971: 115). Known as the "historical particularist" tradition in anthropology, the Boasian approach demanded detailed historical and ethnographic information on particular cases before any generalizations were made. To quote Boas:

When we have cleared up the history of a single culture and understand the effects of environment and the psychological conditions that are reflected in it we have made a step forward, as we can then investigate in how far the same causes or other causes were at work in the development of other cultures. Thus by comparing histories of growth general laws may be found. This method is much safer than the comparative method ... because instead of a hypothesis on the mode of development actual history forms the basis of our deductions (1940: 279).

Fact-gathering on a grand scale became a major focus of the anthropological endeavor under Boas, and the anthropologist's role, a submission to the culture itself. As one anthropologist today sums up the situation, here was "a totally different relation to the object," one in which there was "a commitment to finding the order in the facts rather than putting the facts in order" (Sahlins 1976: 76). 


\section{Diffusion and Culture Area Theory}

With description the prerequisite to theoretical work, "Boasians" devoted a great deal of energy to the construction of culture history. Using archeology, comprehensive field research, and maps detailing the distribution of culture traits, they sought to discover relationships between cultures and to illuminate the nature of cultural change and development.

From this emerged an interest in "culture areas," "cultural complexes," and "culture centers." Designed as a device for historical reconstruction, the "culture area" principle was easily applied to North American Indians for whom a plethora of ethnographic evidence and contrasting environmental settings made them suitable subjects for such analysis. Theories of diffusion were developed to explain specific cultural complexes and similarities between cultures. The publication of Clark Wissler's The American Indian (1917), which delineated culture areas for the entire Western hemisphere, marked a high-point in the mapping of culture areas.

The contributions of diffusionism and culture area theory were numerous. At the theoretical level these often showed that, contrary to evolutionary doctrine, institutions had developed in different chronological orders in different areas. At a methodological level, culture area anthropologists conscientiously integrated laboratory research with field research, thereby making field work the major tool of the discipline. Finally, as a practical contribution, these theorists constructed culture maps which are still useful today (see Voget 1975: 356).

Interest in diffusionism and culture area theory waned, however, as its weaknesses became more and more apparent. Its historical reconstructions, particularly those dealing with the prehistoric period, were criticized as too highly speculative and probabilistic (see Herskovits 1955: 483). In general, anthropologists became increasingly concerned with the internal dynamics of culture, where diffusionist theory, with its emphasis on external "traits," was of limited assistance.

\section{Boas and North American Indian Music}

The North American Indian occupied a key position in this phase of anthropology. Boas himself, for instance, conducted the bulk of his research among the Indians of the Pacific Northwest, and many of his students and associates worked in other parts of North America, for example, Alfred Kroeber (Indians of the 
Southwest and California), Robert Lowie (Plains Indians), Paul Radin (Winnebago Indians), Frank Speck (Indians of the Southeast, Northeast, and Sub-arctic), Leslie Spier (the Klamath Indians), Clark Wissler (the Plains Indians), and Edward Sapir (Plains, Southwest, and Northwest Indians). Only a small number ventured further abroad.

This was an extremely fruitful period for research on Indian music. In the course of their extensive ethnographic research, many students and colleagues of Boas amassed large wax-cylinder collections of songs with comprehensive notes and song-text transcriptions, which they placed in museums and archives. The quality of their research even in an area as specialized as music was remarkable. Boas himself collected and transcribed songs by ear on his first field trip among the Central Eskimo (Boas 1964 [1888]) and later recorded many Northwest Coast songs. Ethnomusicologists today marvel at the quality of this early work. In my own work among the Interior Salish of British Columbia, I am constantly impressed with the ethnomusicological research undertaken by James Teit, a lay anthropologist trained in the field by Boas. Teit recorded hundreds of songs in southern and northern British Columbia between 1915 and 1921 and accompanied these with detailed notes and photographs. ${ }^{4}$ Norma McLeod noted similarly on the work of Frank Speck that "it is a source of wonder to me to read the early works of Speck and to find in them all the wealth of detail a modern ethnomusicologist could desire (along with some aspects we have since forgotten to consider!)" (1974: 102).

Realizing that Western contact was eroding these numerically small and diverse cultures, the Boasians endeavored to find out as much as possible about the disintegrating cultures by interviewing the last surviving elders before they died or lost touch with the old ways. Thus, many came to be known as "salvage ethnographers" whose main job it was to piece together the past. The major limitation to this approach is that they erected a time barrier between themselves and their subjects of study, that is, they saw the cultures in which they worked to be past or removed in time from their own. Hence, although the act of fieldwork eliminated the space barrier between the anthropologist and his study-object, nevertheless the time barrier remained.

This preference for the static past over the dynamic present persists to this day. Some, particularly historians of Indian-White relations, have found this orientation to be extremely partial. For 
example, Ralph Knight, upon reviewing the vast body of literature on British Columbia Indians noted that "one is hard-pressed to discover that, during the last quarter of the nineteenth century and on, Indian peoples every where in the province were working in the major industries of that period" (1978: 8). The anthropologist Harold Hickerson observed the same fact and concluded from it that there are two kinds of Indians, "one is the Indian of ethnology, the other, the Indian of recent history. The first is the Indian of cultural elements: the snowshoe, puberty ceremonies, kinship organization, and the potlatch. The second is the Indian of the mines, the encomiendas, the missions, and the fur trade" (quoted in Martin 1978: 41).

\section{The Birth of Ethnomusicology}

Comparative musicology and Boasian anthropology converged in the United States just prior to World War II. With the rise of Nazism in Europe and the outbreak of the War, many comparative musicologists emigrated to the United States. Most notable among these were a number of students of Hornbostel George Herzog, Mieczyslaw Kolinsky, Klaus Wachsmann, and Curt Sachs. George Herzog was especially instrumental in bringing comparative musicology together with Boas's anthropology at Columbia University. In the process, he was introduced to the world of field research, Native American anthropology, and culture area/diffusion theory. ${ }^{5}$

By the late 1940s and 1950s, this new musicology had attracted a following of young American students, most notably Bruno Nettl and David McAllester (students of George Herzog) and Alan Merriam. By the early 1950s, "ethno-musicology" emerged as a new discipline in the American university, a new discipline seeking to establish itself as a social science. Its identifying contribution was to move the study of music beyond pure musicology to the anthropology of music. But this endeavor encountered a familiar problem: the treatment of cultures as collections of traits versus the understanding of cultures as living wholes.

The early work of Bruno Nettl represents the confluence of comparative musicology and Boasian anthropology. The goal of his first major publication (1954) was to classify North American Indian songs according to "musical areas." 6 In his later theoretical texts of 1956 and 1964, Nettl stressed that this task - the correlation of geographical areas with the stylistic features of the music - should be a major goal of the field. 
While such classification might have some potential, in his efforts to construct such a wide structural map, Nettl encountered serious obstacles. First, data was sparse. Although he was able to draw together the styles of about eighty tribes, this was far from complete. "Hundreds," he wrote, "remain untouched and unknown" (1954: 4). Moreover, what evidence was available was largely in the form of written transcriptions, not even recordings. These transcriptions inevitably incorporated an invisible range of personal idiosyncrasies. Secondly, his study dealt with the structural component of the songs to the exclusion of their contextual background. However, as many have found, often the structure of songs is profoundly affected by the cultural context. In ignoring the distinction between, for example, the structure of ceremonial and non-ceremonial songs, at least one potentially important variable was missing in his analysis. Finally, as the first songs were not even transcribed until the late nineteenth century, Nettl's expressed assumption that he was dealing with a conservative corpus of songs relatively unchanged since 1500 (ibid.), rests on an unreliable empirical basis (ibid.).

Like Nettl, Alan Merriam drew upon training in comparative musicology (under Meiczyslaw Kolinsky) as well as training in Boasian anthropology (under Melville Herskovits). Herskovits had high hopes for ethnomusicology, this new branch of social science, for he believed that music held the key to deep cultural understanding. As one of the last exponents of culture area theory, he urged his budding students of ethnomusicology to pursue culture area studies (see Merriam 1963: 79-80).

In his classic text, The Anthropology of Music (1964) (dedicated to the memory of Herskovits), Merriam criticized the purely technical analysis of music and proclaimed the study of music sound in abstraction to be meaningless. He advocated instead that ethnomusicologists redress the imbalance between the study of music sound and the study of the cultural context of the music. Music should, he said, be understood in light of musical concepts and behavior (see Merriam 1964: 14-15).

Applying his theory to Flathead Indian culture in a later monograph (1967), Merriam fell short of his expressed ideals. Like his forebears, of whom he was critical, Merriam devoted the major portion of his study to the statistical aggregation of musical traits. His purpose was to determine whether the structure of Flathead music was closer to Plains or to Northwest Coast music, and to trace the routes of diffusion of Flathead music. A central goal of 
this work was "to view Flathead music, insofar as possible, as a continuum from 1805 to the present" (1967: x). With only postcontact, fragmentary data available to him, however, such an objective was difficult to attain. Not surprisingly, Merriam was criticized for failing to merge his musicological analysis with an anthropological analysis. As one critic expressed it:

Merriam's musical analysis of the Flathead songs reveals quite a paradoxical situation: while the author strongly rejects any kind of analysis that approaches music as an isolated phenomenon rather than treating it as a product of human creative behavior, he does not do justice to the specifically musical features of the Flathead songs; instead, he is mainly concerned with a mechanistic investigation of isolated elements divorced from their structural function (Kolinsky 1970: 77).

In theory, therefore, while early American ethnomusicologists appreciated the importance of treating music as a cultural phenomenon, in practice it remained an abstraction divorced from culture. Indeed, most commentators lacked that long and intimate contact with song-makers in their cultural settings which could have taken them beyond the abstract level. Some one-month or several month-long trips were made to Indian reservations, but in general, the ethnomusicologist, like his comparative musicological forebear, preferred the laboratory to the field.

There were, of course, some notable exceptions. Frances Densmore was one. She was among those rare individuals (more common in the field of British and European folksong collecting) who was not affiliated with any particular school of anthropology or comparative musicology. Following her early music training at Oberlin College, she began, in 1893, at the age of twenty-six, to record the music of the Chippewa Indians living near her home in Minnesota. By the 1940s, she had recorded well over 2400 Indian songs under the auspices of the Bureau of Ethnology (see Lurie 1966: 69).

Densmore was a "romantic." Her passion for recording was motivated by the painful reality of a successful way of life being extinguished before her. Scientific theories, transcription techniques, and modes of analysis were not her primary concern. Yet, it is in these latter areas where her work has been criticized while her special insights derived from her unique involvement with the music-makers have been neglected. To Densmore, the goal was "to discover what music means to the Indian and to describe it from his standpoint" (1968: 78). The result was a fundamental 
departure from mainstream theoretical concerns, a fact which is illustrated in some of her writings. "Music," she explained, "to Indians ... is connected with power and with communication with the mysterious forces that control all human life. In that, even more than in the sound of the singing, lies the real difference between the music of the American Indian and that of our own race." Indeed, the vast gulf between the music of her own culture and that of the Native American had a profound effect upon her. Unlike the white composer, she wrote, who "regards the song as a possible source of applause or wealth," the Indian "waited and listened for the mysterious power pervading all nature to speak to him in song. The Indian realized that he was part of nature - not akin to it" (ibid.: 78-79). Beyond denigrating her transcription ability, there is a need to re-examine her perspective and to appreciate the full importance of such insights.

David McAllester is another whose emphasis upon the field phase of his research among the Navajo led him to make important anthropological connections between personality and music (see McAllester 1954).

\section{Anthropology and Acculturation Theory}

Despite the popularity of ethnographic mapping, it soon became apparent that diffusionist theories were ill-equipped to deal with the cultural changes brought on by colonization and industrialization. To account for the determinants of recent change, such as how culture was learned, and why or when culture traits were dropped or exchanged during sustained culture contact, theories of acculturation were developed.

Acculturation was defined in 1936 as "those phenomena which result when groups of individuals having different cultures come into continuous first-hand contact, with subsequent changes in the original cultural patterns of either or both groups" (Herskovits 1938: 10). The acculturative process was noted to vary significantly from area to area with some groups being divested of their political and cultural autonomy, others resorting to various forms of reactive adaptation (such as "reinterpretation" and "syncretism") and some others even withdrawing from the contact situations to turn in upon their own cultural traditions.

The potential of acculturation theory has, however, remained largely unrealized due to the restrictions imposed upon it by the scientific/objective approach. One of its strongest exponents, Melville Herskovits, for example, believed that evaluations 
between "higher and lower" or "active and passive" bodies of tradition could not be made. Passing judgment upon the acculturative process was not considered part of the anthropological mission. "One party of the contact must not be approached with an a priori assumption of its greater significance than another... [and] it is not to be taken for granted that native civilizations must eventually give way before European or American culture" (1938: 119). He believed further that although a group which sees itself as socially inferior will borrow more extensively from its "superiors" than vice versa, this will not necessarily result in its disintegration: "Though stronger peoples have imposed their wills on weaker ones, these have made their adjustments, completed their acculturation, and survived to carry on their lives and much of their earlier tradition" (1938: 52).

\section{Acculturation, Ethnomusicology, and the North American Indian}

Acculturation is an anthropological perspective which has proved itself to be particularly adaptable to musical phenomena. For the fledgling ethnomusicologist, for example, acculturation has served as a vehicle for the redirection of concerns from the pure and uncontaminated musics of the past to issues of contemporary change.

One of the first attempts made to draw ethnomusicology into acculturation theory was a paper presented in 1949 by Willard Rhodes entitled, "Acculturation in North American Indian Music" (1967 [1952]). Numerous other articles followed Rhodes's lead ${ }^{7}$ generating several hypotheses on the subject. One of the more notable was put forward by Bruno Nettl who argued that in order for acculturation to take place between two musical cultures, "the musical corpora must in some way be stylistically compatible" (1964: 172). Nettl drew his conclusion from the following: 1) the differences and therefore the lack of cross-fertilization between Amerindian and Amer-european music; and 2) the compatability and therefore the blending of African and European musics.

Alan Merriam's findings among the Flathead corroborated Nettl's theory. Flathead music in the 1950s, despite its exposure to European music, showed hardly a trace of Western influence (see Merriam 1955: 34). According to Merriam, this act of "compartmentalization" indicated that the Flathead almost consciously kept the two styles separate, choosing to drop segments of their music as the occasions for using them disappeared rather than to blend the two (see Merriam 1967: 123). Compartmentalization and 
musical attrition appeared to be typical of North American Indian music in the 1950s and early 1960s, while European and African musical systems showed an exchange and blending of the systems.

The most notable observation on acculturation in North American Indian musics was that the once widely diverse Indian musics were being reduced to an essentially homogeneous panIndian conglomerate. As Nettl explained: "Just as they frequently have given up tribai identity in favor of a general 'Indian' identity, they have given up tribal styles in favor of a pan-Indian style based mainly on Plains singing as an alternative to giving up Indian music completely" (1966: 137). Studies also described the finer characteristics of the Plains pan-Indian style, the loss of localized styles and repertories, new compositional techniques, the introduction of English song-texts, Christian hymn singing, and the use of new materials in the construction of musical instruments (see Nettl 1966: 131-34; Merriam 1955).

Despite such noteworthy observations, however, acculturation theory in ethnomusicology made relatively little analytical headway. One problem was that the focus of these studies tended to be exclusively on the outcomes rather than the process of change. Issues such as the determinants of this change or the future of Native Indian music were relatively neglected. As with earlier approaches, this failure to consider the dynamics of interaction stemmed from ethnomusicology's fractionated interpretation of culture as "traits." In the name of acculturation, musical traits and musical instruments could be approached as "things" exchanged and adapted in the face of culture contact. In the process, the vision of culture as a living totality was sacrificed for the vision of culture as a series of traits.

In addition to this scientific fragmentation, the "objective" goals of acculturation research limited its consideration of the impact of Western dominance, even though Western dominance had clearly been a major variable in the musical change. Thus, ethnomusicologists carefully avoided the value-judgments inherent in evaluating a situation as a case of "musical loss" or "cultural deterioration." Instead, ethnomusicology incorporated the alternative ideologies which assert that "change is a constant" or that people will give and take but will also "grow" musically. In this way, musical acculturation studies did not examine critically the underpinnings of the acculturative process, especially the colonizing effect of new economic forces upon the music of preindustrial societies. Instead, they merely accepted the status quo 
as a cultural given. As one ethnomusicologist expressed it, "the fears for the destruction of the music of the 'folk' often tend to be overemphasized, and there is implied a failure to consider the inevitability of change" (Merriam 1964: 9).

This position is still widely held. Rejecting the fears of Alan Lomax, who for years has argued in relative isolation that we are heading towards a "cultural grey-out" (the ongoing dilution of small cultures by dominant ones), Bruno Nettl recently wrote albeit in a most contradictory and equivocal fashion that:

... the coming of Western music has not stamped out the existence of non-Western styles; it may have reduced them, changed them, recast them for different uses, but in some form, in many forms, they have continued to exist (1978: 130).

Similarly, David McAllester, upon noting as one sign of musical change, "the great surge of interest in powwow music" and the "parallel interest in Rock" among most American Indians, cautioned that:

After all our impulses to cherish and protect, we should realize that human culture is not a flower with fragile petals ready to drop at the first frosty touch of a new idea...

I see new cultures, large and small, emerging all around us, and I rejoice that the human species and what we create are so varied, so variable, and so interesting (1979: $181 \& 189$ ).

In contrast, Stanley Diamond and many other anthropologists have begun to assert a radically opposing point of view. To them, "acculturation has always been a matter of conquest" (Diamond 1981 [1974]: 204). Here is an important opportunity for ethnomusicology to make a contribution to a larger field of debate. But, by aspiring to a disinterested scientism in a period of unprecendented cultural destruction, acculturative research in music has brought us little closer to the what and why of culture and culture change. This is, however peripherally, beginning to change.

\section{Ethnomusicology and Science}

That contemporary ethnomusicology aspires to the status of a modern social science is most clearly articulated by Alan Merriam in his book, The Anthropology of Music. Ethnomusicology, explains Merriam, "sciences" about music (1964: 25); it communicates "knowledge" rather than emotion; and it is objective, quantitative, and theoretical in its orientation as opposed to the 
humanities which are subjective, qualitative, and discursive (ibid.: 20). Its methods are the methods of the sciences, that is:

... the formulation of hypotheses, the control of variables, the objective assessment of data gathered, and the grouping of results to reach ultimate generalizations about behavior which will be applicable to man rather than any particular group of men (ibid.: 37).

The ethnomusicologist is an objective "outsider who seeks to understand what he hears through analysis of structure and behavior and to reduce this understanding to terms which will allow him to compare and generalize his results for music as a universal phenomenon of man's existence" (ibid.: 25).

By modelling itself as another science, ethnomusicology is prey to the challenges to scientific thinking that have grown in force in recent years. For example, "objectivity," so fundamental to empiricism, has been challenged in the physical sciences where the Heisenberg Uncertainty Principle has demonstrated the inability to separate the observer from the observed. Similarly, the logical method has encountered its limits. Mathematics, the purest of the sciences, is ultimately dependent upon some final "undefined terms," which has the effect, in short, of rendering logic accountable to intuition. (This is the well-known debate between the "logicists" and the "intuitionists.") In addition, recent theorists have demonstrated that no logical system is capable of complete consistency (the so-called "Godel's proof"). Logic is, in the words of philosopher Alfred North Whitehead, "a fake." 8 The weaknesses in these components of the scientific method, empiricism, and logic, point to the inescapable impact of one's physical being in shaping one's perception of reality. There is no us-and-them, no subject and object. These weaknesses, in conjunction with the devastating practical consequences of science and technology, have led to Herbert Marcuse's famous call for a "new science" (1964: 144-69)..$^{9}$

In the social sciences, the myth of objectivity has long been challenged by the "critical theorists" (such as Marcuse) of the Frankfurt School. The anthropologist Bob Scholte demonstrates how a colonial ideology is inherent within the very notion of a neutral anthropological science:

In anthropological description ..., value-freedom amounts to 'une pureté analytique, illusoire,' not merely because 'the act of detached observation ... dehumaniz[es] the observed [and] 
reduces him to an inferior position,' but also because ... the colonial system is simply and uncritically taken for granted (1978: 182).

A similar argument was made by Kenneth Gourlay in an article entitled "Towards a Reassessment of the Ethnomusicologist's Role in Research" (1978). He tried to show that much of what is claimed to be "value-free" is, upon closer examination, a complex value-projection and hence, can never be neutral or detached.

Having ignored a key variable in its research design - the worldview of the subject, the researcher - an entire era of scientific "interpretive" ethnomusicology requires re-appraisal. Understanding has been reached via a one-way street, that is through the translation of the experience of the object/informant into the terms of the subject/researcher. One of the more common examples of this is the assumption that the observer's intellectual, visual, and secular concept of music is somehow a valid point of reference for the observed even though the musical worldview of the Westerner and the non-Westerner are often radically different. As one musicologist recently pointed out:

What the westerner is taught and trained to focus on in music is ... the chain of interlinked units.... Each such unit is perceived and identified as a particular item and object with certain fixed properties - location (pitch, register), length (duration), force (loudness), coloring and weight (timbre), density (texture), and function (place and rule in the hierarchy and dynamic relations between the units) (Orlov: n.d.).

In contrast, much music throughout the world (North American Indian music, for example) is:

... not "becoming," never "complete," but always travelling and is perfect at every instant of its existence. It is living indeed, calling the listener to live its life, to participate in it from the birth 'till the death of the sound, not to observe and to estimate (ibid.).

In short, there is, on the one hand, an overwhelming tendency to have "to do" something with time, and, on the other, simply the desire "to be" in time (ibid.).

Such scientific analyses have been imposed on many facets of the North American Indian musical experience which simply do not lend themselves to such interpretation. For example, the Flathead Indians of Montana believe that their guardian spirit songs come directly to them in a moment of the supernatural. 
Merriam, in his monograph on Flathead music on the subject of these songs, made note of the native belief but added his own interpretation, which he admitted was "in no way reasonable to the Flathead themselves," - that the Flathead deliberately and consciously created or composed their guardian spirit songs (1967: 9). The result was that by taking his own attitude as given, Merriam denigrated and denied what was the essence of the Flathead musical and spiritual experience.

Similarly, despite the fact that most North American Indian texts and melodies are not fixed in time but fluctuate according to the momentary dictates of feeling or verbal necessity, ethnomusicologists continue to submit them to musical notation, thereby drawing them out of their own cultural frame and into that of the West. What occurs in this process is the transformation of an essentially total experience into a rational mode of comprehension. In the case of Bruno Nettl, who counts and records the smallest time-units in a particular corpus of Indian songs (see Nettl 1964: 156), this process is taken to its extreme, artificially imposing fragmentation and discontinuity upon a musical consciousness whose essence is participation and continuity.

The scientific objectives of ethnomusicological research also leads to the elevation of "testable data," usually the external characteristics of music, because these can be preserved on magnetic tape. This leads to de-emphasis on those aspects which are not so easily quantifiable - the sensibility behind the sound and other elusive, "unknowable," and unpredictable qualities of music and musical experience. When the scientific ethnomusicologist has completed his tasks, what is left is often no longer music in the native sense, but rather "mental models ... that are understandable just because they are the creation of his own mind... These mental models serve as maps or blueprints of reality..." (Blackburn 1971: 1005).

Non-traditional approaches to non-Western musics, such as John Miller Chernoff's African Rhythm and African Sensibility (1979), emanating from the author's "love" of Ghanaian drumming, are thrust aside as "humanistic and evaluative." According to Merriam, one "would be ... hard-pressed in explaining its importance as data to a student" (1980: 561). Merriam challenged Chernoff's participation in the music he loved, yet he failed to appreciate Chernoff's important insight that culture can never be truly understood if one does not enter into it, experience it - in short, if one does not lose one's objectivity. ${ }^{10}$ 


\section{Signs of Change}

Chernoff's work is one of numerous signs of redirection within ethnomusicology. Further evidence is to be found in recent critiques of the field. In an article entitled "Should Ethnomusicology Be Abolished?", Frederic Lieberman implied that "academic ethnomusicology as represented by the Society and its Journal... has ... no logical reason for continued existence other than the purely social needs of its members" (1977: 198). The field, he said, had "served its purpose, run its course" (ibid.: 201) particularly as many of its subjects saw it as a form of "neo-colonialism" (ibid.: 199). Kenneth Gourlay put forward one of the harshest critiques to date in an article in Ethnomusicology (1978) in which he challenged the scientific objectivity of ethnomusicology and argued that the ethnomusicologist himself is a "variable" to be accounted for. Still others have argued that much past ethnomusicological activity has been a projection of Western intellectual structures upon other very different cultures. As Charles Keil expressed it:

What could be worse than to take harmonically oriented, architectonic Western music as the model for understanding the world-views of "melody-and-rhythm" peoples in South America? Why play our spatial-visual-vertical-hierarchicalintellectual games with their temporal-aural-horizontal-egalitarian life energies? Instead of applying our ordering principles to their energies, we should be tapping their energies to undermine our order, to criticize and revitalize, if possible, our existence (1979: 183).

In place of traditional "objectivity," some musicological analysis is beginning to adopt a self-reflexive (dialectical) approach, "an extended exercise in looking at self and society through the medium of music" (Shepherd 1977: 113). The study of non-Western musics is particularly useful in this regard, for it helps illuminate the nature of our own musical/cultural conditioning. As Edward Rothstein recently commented:

We are so cosily embedded in our musical culture that we take it to be almost natural. The concert hall with its numbered seats, the concert artist with the prepared repertory, the concert review with its somber pronouncements, the agents with publicity angles - these aspects of contemporary musical life are as expected and invisible as a waiter in a restaurant or the shape of a vest in a man's suit (1982: 21 ). 
In fieldwork too, more ethnomusicologists are seeking a more intensive participation with their so-called "informants." A deeper, even co-operative understanding is emerging as a result. For example, Donald Bahr and J. Richard Haeffer, working with a Piman Indian from the American Southwest have developed a mode of musical transcription sensitive to Piman concerns rather than to those of traditional ethnomusicology. They write:

Pimans do not write songs for their own use and have made little use of the academic literature on their music. Many Pimans dislike this literature as it permits songs to pass out of native control. Our method of writing songs is a response to this feeling. As a printed transcript has the potential of being read aloud, the songs are written below without melodic transcriptions so they could not possibly be sung. In this manner we recognize that the reader and the Pimans inhabit the same world (1978: 92).

In their autobiography of a highly respected Blessingway singer, Charlotte Frisbie and David McAllester (1979) employed a colloquial style of English speech typical of the Navajo. They also drew the members of the Mitchel family into the translation process.

In-depth participation in cultures (fieldwork) combined with greater fluency in the languages of those cultures have led to new methods of discovery, more humanistic and participatory then the "transcription/analysis" technique. In an article on the Suya Indians of Central Brazil, "What Can We Learn When They Sing?", Anthony Seeger explained, "'collection' must be a prolonged interpretive process. Obtaining music in its social context means waiting for it to be performed rather than collecting recordings from individuals on short collecting trips" (1979: 391). Others, such as Barbara Tedlock and William Powers have engaged in deep linguistic analysis in order to get closer to the native musical concepts. As a result, both Tedlock in her work with the Zuni (1980) and Powers in his work with the Oglala (1980) have challenged the long-held theory that Indians do not verbalize about their music. Tedlock has found that the Zuni have a large native song-classification system which involves a full and conscious command of such areas as the grammar of songcomposition and pitch-contour (1980: 33). Powers took his findings one step further and developed a dialectical "synthetic/ analytic contrast" for understanding the musical terminology of the Oglala tradition in relation to the Western tradition (see Powers 1980). He stressed that much confusion has resulted from 
the tendency for the preconceptions of the analytical model to be laid upon that of the synthetic. Christopher Small's recent work, Music.Society.Education (1977) and others which undertake indepth critical anthropological analyses of the Western musical tradition, made a major contribution to a more self-critical and self-aware understanding of world musics.

\section{Change is a Constant}

Ethnomusicology's ideal of objective observer and its uncritical faith in the adaptability of man continue, however, to impede this transition. Most ethnomusicologists consider it beyond their domain to act as participants in culture and especially to take a consciously activist stance. Instead they unwittingly (but no less actively) perpetuate the Western belief in progress projected as the goal of humanity (see Diamond 1974: 39-40). In the process, other ideals of Western individualist ideology - diversity and pluralism - are rendered illusory because they are applied exclusively to individuals living in a Western mode, not to cultures and societies pursuing their own diverse identities.

The Western assumption of the domination of non-Western cultures permeates the anthropological endeavor in general. It is, for example, disturbingly evident in a recent publication issued by the Smithsonian Institution outlining its programs:

In view of the accelerating westernization of all cultures, the Smithsonian has initiated a cooperative program of urgent anthropology to assist in recording, with scientific precision, as much data as possible on the cultural variability that still exists. Scientists may never again have a chance to observe such a great range of human differences....

Many remarkable and informative natural experiments in living have emerged in different corners of the world during thousands of years of independent cultural evolution. Now, unprecedented in all human history, this independent diversity is coming to an end in the face of world wide modernization.... So that we might not lose the unique insights into the nature of humankind ... we are systematically preparing detailed permanent, synch-sound film records ... as a permanent scholarly resource (Smithsonian 1979: 18 \& 20).

Human cultures and societies in this are seen only as "experiments in living" and "resources" which can be reduced to "data" infinitely retrievable on "synch-sound" film. This activity of rationalizing 
all knowledge reflects not pure "science" but the compulsions of a society out of touch with the very experience of living culture.

As we have seen, mainstream post-War ethnomusicology adopted the scholarly injunction not to meddle in the object of study (Merriam 1964: 25). This value-free orientation coupled with a deference to the momentum of domination explains the prevalence of descriptive analytical writing over that which is emotional, psychological, and subjective Typical is the recent volume of Selected Reports in Ethnomusicology which presents an idyllic picture of aboriginal Indian music. Despite "conquest, intermarriage, relocation and urbanization," Indian music, writes Charlotte Heth, editor of the volume, "has not disappeared... Although Indians have composed music to fit the times, they have also performed their oldest songs again and again" (1980: xii). Through the course of reading these articles - ranging from an analysis of a Navajo poem, an explanation of Oglala song terminology, a study of Ojibwa song-form, the San Juan Turtle dance, the Pogonshare Ceremony of the Tewa, categories of musical performance of the Choctow Indians, and conjuring songs of the Eastern Cherokee (all of which the editor explains represent "current scholarship trends") - one is led to believe that all is well and thriving on Indian reservations in the 1980s.

On the other hand, when one approaches the Indian from non-academic channels, especially through native political and cultural publications, one discovers a quite different situation. In these latter publications the tone is of an urgent concern for cultural survival. From this one begins to sense that there are indeed two Indians, one of academia and the other of contemporary politics. Not surprisingly, the real contemporary Indian is increasingly less willing to play the part of the other "informant" Indian. According to one article in Akwesasne Notes:

Anthropology concerns an individual who goes into a community, learns, ... writes his books, publishes it in another system - one altogether different from the one he has just learned from and studies.... The anthropologist does that as a career, as an identity, as a way of life ... while the people that he studies are ... disrupted, having given the very heart of their perception of themselves and their world. This is extractive to us. In no small measure, a rip-off. Anthropology serves ... the so-called "body of knowledge" that Western education systems of higher learning seem to cherish so much. Overall, as far as we can tell, it does nobody in the communities any good (Ismaelillo 1978: 20-21). 


\section{Ethnomusicology and Self-reflexive Criticism}

Today the old music-makers continue to disappear before what might be called economic music - mass-produced, massdisseminated music that is a product of the dominant economic culture. It is this larger structure against which so many Indian peoples today - whether North or South American, Asian or Australian - struggle. At this critical juncture of human history an evaluation of ethnomusicological values, assumptions, and objectives is needed.

The first step in this must be a thorough critical review of the premises of ethnomusicology's dominant paradigm - a review which is occurring in many spheres outside of ethnomusicology. Side by side with the historical march of the scientific Enlightenment, many also now see a history of Western conquest of nature and of autonomous cultures. Many allege that the discipline of anthropology itself had an important supporting role in this political process. If ethnomusicology and anthropology are to play a more conscious and constructive role in the contemporary context - a trans-ideological role - they must study and question their premises and reconstitute themselves as sciences of living cultures and community. In the end, they must not take refuge in some false objectivity but commit themselves to "the struggle for the creation of culture against collective and dehumanizing forces..." (Scholte 1978: 185).

Few in ethnomusicology have taken up this banner. Charles Seeger was one who did use music in the 1930 s to cope with social and economic problems. "We felt urgency in those days," he explained. "The economic and social system [was] going to hell over here. [We believed that] music might be able to do something about it.... [We felt] we must try. The musician who doesn't feel he must try is no good" (1980: 162).

Alan Lomax is one ethnomusicologist who has carried these concerns into the present. For years now he has argued that a "cultural grey-out" (1980: 22) is subsuming the globe, "the total destruction of cultures ... the consequence of laissez-faire mercantilism, insatiably seeking to market all its products, to blanket the world not only with its manufacture, but with its religion, its literature and music, its educational and communication systems" (ibid.: 24). "It is ironic," continues Lomax, that:

... during this century, when folklorists and musicologists were studying the varied traditions of the peoples of the earth, their rate of disappearance accelerated.... We have grown so 
accustomed to the dismal view of the carcasses of dead or dying cultures on the human landscape, that we have learned to dismiss this pollution of the human environment as inevitable, and even sensible, since it is wrongly assumed that the weak and unfit among musics and cultures are eliminated in this way (ibid.: 22-23).

When one reflects carefully on these facts, the need for participation grows ever more urgent. For it is also our own survival which is in issue.

For guidance in this mission, one must begin a re-appraisal of other ages and other societies in order to discover what these people knew or know of our individual human and collective social natures. In this, there is a new and valuable role for ethnomusicology. In the West, we have ignored the interdependence and unity of all things and have focused instead upon issues divorced from a natural and social context. This is evident in the technical/analytical orientation in ethnomusicological theory, from its comparative musicological roots through its fragmented treatment of culture areas to our still dominant mode of transcription and analysis. What is necessary to transcend this situation is to re-establish ourselves, our music, and our studies within a living social and natural context. Herein lies the value of Indian music, an orientation towards the experience/being (as opposed to scientific analysis) of that music, an orientation that provides not just analytical knowledge but which actively promotes physical, natural, social, and spiritual integration as an avenue to truth. Such an "ecomusicology" focuses the meaning on this social and natural interdependence - that is, as music in its relation to our human communities and their natural environments.

Kenneth Gourlay is one of the ethnomusicologists trying to address such issues today. In a recent article, "Alienation and Ethnomusicology," he urges his readers to rethink the meaning of "context" and to consider the "communicative event" as a totality:

Music exists only in performance, not in a tape-recorded abstract of one aspect, or in a score, which only tells men and women what to do and when to do it, or even in the most accurate melographcomputerized transcription, which only translates abstracted "sound" into equally abstracted sight. For "performance" is the activity of men and women living in, and limited by, a particular culture ... who, at a particular time and place, draw on past experience and present knowledge of social values, methods and 
relations to express themselves.... In ethnomusicological research, we must begin not with sound - nor even with sound and context - but with human activity expressed through the total sound-context event (1980: 142).

Yet, even this new "perception" is not enough unless it exists as part of a larger attempt to replace the traditional subject-object orientation with a new awareness of the inter-relation between observer and observed. A number of social scientists are pursuing such a course. What they are proposing as an alternative to "scientific observation" is "dialectical communication" - interactive exchange (communication) between individuals whose bases of information may be fundamentally different. The goal of this, it is hoped, will be a transcendence rather than an entrenchment of these differences (see Fabian 1971: 41; Scholte 1978). Jürgen Habermas views the situation in which everybody participates equally in explanation and interpretation to be crucial to life free from domination and manipulation (see Habermas 1970). The "dialectical" ethno- or eco-musicologist thus undertakes a critical and self-reflexive analysis of his own cultural conditioning not by data-gathering but by apprenticing himself to his or her former "object" or "informant." To quote Gourlay once again:

A humanizing ethnomusicology seeks to bring the two world views into an interpenetrating dialectical relationship through which the investigator is himself investigated so that the process becomes one of re-creation (1982: 416).

Music is particularly central to this new communication because music is, in its essence, a physical experience that cannot be reduced to a purely rational process of communication. The transition to eco-musicology thus necessitates looking beyond scientific data and theoretical hypotheses to the shared experience of being. It requires a recognition that neither a culture nor its music can be truly understood if one does not enter into it, and feel it - to repeat, if one does not lose one's objectivity. Deep involvement of this sort should lead to a new starting place beyond explanation which admits the wisdom of intuition, the power of feeling, and the truth of experience. It should also lead not to a rejection of, but a new context for, science and logic. This is the ecological dialectic of consciousness and being - the recognition of the mind's illusions of its own autonomy. A true rationality is located not in the "abstract mind" but in the physical brain; not in the logical process but the total experience; not in the technician, 
but the person. In other words, for the Western rationalist, ours is a task which, "in encounters with unalienated peoples of nonelitist-integral societies, necessitates at least a partial overcoming of our own alienation" (Gourlay 1980: 138).

Thus, the ultimate challenge is to transform our anthropologies from instruments of "conquest and oppression" to an "exchange between equals." Then our field may no longer be one justified by an illusory and futile "pursuit of knowledge" or the meaningless pursuit of, as Akwesasne Notes alleges, career advancement. Instead it will serve a truer and also more noble purpose: to "become apprentices to those primitive peoples whose cultures hold out the promise of a more creative society" (Scholte 1978: 185). As the sociologist Bill Devall has expressed it:

Person (the self as part of the great Self)-polis (as community self-regulated by custom and ecological insight)-cosmos (men as "plain citizens" not master of the planet) are united in the contemporary search for the 'future primitive'... (1982).

In its new form, the object of the eco-musicological task becomes not merely the analysis of intervals and pitch, but the understanding of consciousness of society and nature. As Stanley Diamond has so passionately expressed, we search for the "primitive" in order to regain the sense of the totality and immediacy of human experience which we, as members of a highly technological industrial society, have lost (see Diamond 1969). Ultimately, the eco-musicologist is not only aware of our differences but committed to their survival in harmony in the places where they are. Such a quest could transform us all. In the words of Anthony Seeger, "ultimately, we shall have a better understanding of ourselves and our own music when we know, for example, why the Suya sing for their sisters and we do not" (1980:40). 


\section{NOTES}

1. The doctoral dissertation referred to (Über die Musik der nordamerikanischen Wilden) was undertaken by Theodore Baker (1882) at the University of Leipzig. Three of the four founding members of the Society for Ethnomusicology in 1955 were noted North American Indian music scholars, namely, David McAllester, Alan Merriam, and Willard Rhodes.

2. "Western" as used throughout this paper refers to the elite literate cultures of Europe and the Americas of the last approximately three centuries.

3. Among those who have conducted short historical summaries of the field are the following: Curt Sachs (1962); Jaap Kunst (1974); Bruno Nettl $(1956 ; 1979)$; and Norma McLeod (1974). One of the most recent is by Bruno Nettl (1983).

4. This work was undertaken under the auspices of Edward Sapir at the Victoria Museum (now the National Museum of Man, Ottawa, Ontario). Teit's field materials are now part of the permanent collection of the Canadian Ethnology Service, National Museum of Man, Ottawa, Ontario.

5. Although George Herzog produced no monographs on Indian music, he authored a long series of articles on the subject, most notably on Yuman, Plains, Great Basin, Pueblo, and Pima music.

6. In this, he was following in the footsteps of his teacher, George Herzog, who had earlier published a preliminary statement on musical areas entitled "Musical Styles in North America" (1928). Nettl's own publication, "North American Indian Musical Styles" (1954), was based upon his doctoral research, directed by Herzog.

7. For other key articles on musical acculturation, see Merriam (1955), Wachsmann (1961), List (1964), and Nettl (1966).

8. For a recent discussion of the issues by an established historian of science, see Morris Kline, Mathematics: The Loss of Certainty (1980: 315).

9. For a larger discussion of the limits of science, see Fritzhof Capra, The Tao of Physics (1976); Thomas Blackburn, "Sensuous-Intellectual Complementarity in Science" (1971); William Barrett, The Illusion of Technique: A Search for Meaning in a Technological Civilization (1978); and Morris Kline, Mathematics: The Loss of Certainty (1980).

10. Historical musicology retains a similar perspective. For example, Wilfred Mellers has recently broken away from the strictly technical analysis of Western music by considering Bach, not just as a producer of abstract art, but as a socio-historical figure. His Jungian and Marxian analysis was harshly criticized by one musicological colleague who demanded a "more strictly technical analysis" (Kerman 1981: 6 \& 8). 


\section{REFERENCES}

ABRAHAM, O. and HORNBOSTEL, E.M. von.

1975: "Phonographierte Indianermelodien aus Britisch-Columbia" (1906) ["Indian Melodies from British Columbia Recorded on the Phonograph"]. Translated by Bruno Nettl. In Wachsmann, K.P., Christensen, D., and Reinecke, H.-P., eds., Hornbostel Opera Omnia, I: 299-322. The Hague: Martinus Nijhoff.

ALLEN, W.D.

1962: Philosophies of Music History: A Study of General Histories of Music 1600-1960 (1939). New York: Dover.

BAHR, M. and HAEFFER, JR.

1978: "Song in Piman Curing," Ethnomusicology XXII/1: 89-122.

BAKER, T.

1976: On the Music of the North American Indians (1882). Translated by Ann Buckley. Buren Netherlands: F. Knuf.

BARRETT, W.

1978: The Illusion of Technique: A Search for Meaning in Technological Civilization. Garden City, New York: Anchor Press.

BECKER, E.

1971: The Lost Sciences of Man. New York: George Braziller. BLACKBURN, T.R.

1971: "Sensuous-Intellectual Complementarity in Science," Science, CLXXII/3987 (June 4), 1003-07.

BLUM, S.

1975: "Towards a Social History of Musicological Technique," Ethnomusicology, XIX/2, 207-31.

BOAS, F.

1887: "A Year Among the Eskimo," Bulletin of the American Geographical Society XIX, 383-402.

1964: The Central Eskimo (1888). Lincoln: University of Nebraska Press.

1940: Race, Language and Culture. New York: McMillan.

BURROW, W.

1966: Evolution and Society. Cambridge: University of Cambridge Press.

CAPRA, F.

1976: The Tao of Physics. London: Fontana/Collins.

CHERNOFF, J.M.

1979: African Rhythm and African Sensibility: Aesthetics and Social Action in African Musical Idioms., Chicago: University of Chicago Press.

COMMAGER, H.S.

1977: The Empire of Reason. New York: Anchor Press. 
DENSMORE, F.

1968: Frances Densmore and American Indian Music: A Memorial Volume Compiled and Edited by Charles Hofmann. Contributions from the Museum of the American Indian, Heye Foundation, XXIII. New York: Museum of the American Indian, Heye Foundation.

DEVALL, B.

1982: "Muir Redux, From Conservation to Ecology, 1890-1990" (Unpublished $\mathrm{ms}$. in the author's possession).

DIAMOND, S.

1969: "Anthropology in Question," in Hymes, D., ed., Reinventing Anthropology. New York: Vintage Books, 401-29.

1981: In Search of the Primitive (1974). New Brunswick, N.J., Transaction Books.

FABIAN, J.

1971: "Language, History and Anthropology," Philosophy of the Social Sciences, I/1, 19-47.

FEWKES, J.W.

1890a: "A Contribution to Passamaquoddy Folk-lore," Journal of American Folklore, III (October-December), 257-80.

1890b: "On The Use Of The Phonograph Among The Zuni Indians," American Naturalist, XXIV, 687-91.

FLETCHER, A. and LA FLESCHE, $F$.

1893: A Study of Omaha Music. Cambridge: Archaeological and Ethnological Papers of the Peabody Museum, I/5, 231-382.

FRISBIE, C. and McALLESTER, D.P.

1979: Navajo Blessingway Singer. Tucson: University of Arizona Press.

GOURLAY, K.A.

1978: "Towards a Reassessment of the Ethnomusicologist's Role in Research," Ethnomusicology, XXII/1, 1-35.

1980: "Alienation and Ethnomusicology," in Norma McLeod and Marcia Herndon, eds., The Ethnography of Musical Performance. Norwood, Penn.: Norwood Editions, 123-46.

1982: "Towards a Humanizing Ethnomusicology," Ethnomusicology, XXVI/3, 411-20.

HABERMAS, J.

1970: Toward A Rational Society. Boston: Beacon Press.

HARRIS, M.

1968: The Rise of Anthropological Theory. New York: Thomas Y. Crowell.

HERSKOVITS, M.

1938: Acculturation: The Study of Culture Contact. New York: J.J. Augustin.

1955: Cultural Anthropology. New York: Knopf. 
HERZOG, G.

1928: "Musical Styles of North America," in Proceedings of the 23rd International Congress of Americanists, 455-58.

HETH, C., ed.

1980: Selected Reports in Ethnomusicology, II/2. Los Angeles: Program in Ethnomusicology, Department of Music, University of California.

HORNBOSTEL, E.M. von

1975: "Die Probleme der vegleichenden Musikwissenschaft" (1905) ["The Problems of Comparative Musicology"]. Translated by Richard Campbell. In Wachsmann, K.P., Christensen, D., and Reinecke, H.-P., eds., Hornbostel Opera Omnia, I: 247-70. The Hague: Martinus Nijhoff.

HORNBOSTEL, E.M. von and CURT SACHS

1914: "Systematik der Musikinstrumente," Zeitschrift für Ethnologie, XLVI, 553-90.

ISMAELILLO

1978: "Identity and Commitment: Some Comments on a Symposium

KEIL C. of Anthropologists," Akwesasne Notes, X/2, 20-21.

1979: Tiv Song. Chicago: University of Chicago Press.

KERMAN, J.

1981: "A Bachward Glance," The New York Review of Books, XXVIII $/ 15,6$ \& 8 .

KLINE, $M$.

1980: Mathematics: The Loss of Certainty. New York: Oxford University Press.

KNIGHT, R.

1978: Indians at Work. Vancouver: New Star Press.

KOLINSKY, M.

1970: "Review Essay" (Alan P. Merriam, Ethnomusicology of the Flathead Indians), XIV/1, 77-99.

KUNST, J.

1974: Ethnomusicology, 3rd. ed. The Hague: Martinus Nijhoff.

LIEBERMAN, F.

1977: "Should Ethnomusicology Be Abolished?" College Music Symposium, XVII/2, 198-201.

LIST, G.

1964: "Acculturation and Musical Tradition," Journal of the International Folk Music Council, XVI (January), 18-21.

LLOYD, A.L.

1970: Folk Song in England. (1967) New York: International Publishers.

LOMAX, A.

1968: Folk Song Style and Culture. Washington: American Association for the Advancement of Science. Publication No. 88.

1980: "Appeal for Cultural Equity," African Music, VI/1, 22-31. 
LURIE, N.O.

1966: "Women in Early American Anthropology," in Helm, J., ed., Pioneers of American Anthropology: The Uses of Biography. Seattle: University of Washington Press, 29-81.

MARCUSE, $\mathrm{H}$.

1964: One-Dimensional Man. Boston: Beacon Press.

MARTIN, C.

1978: "Ethnohistory: A Better Way to Write Indian History," The Western Historical Quarterly, IX/1, 41-56.

McALLESTER, D.

1954: Enemy Way Music. Cambridge: Peabody Museum Papers, $\mathrm{XLI} / 3$.

1979: The Astonished Ethno-Muse," Ethnomusicology, XXIII/2, 179-89.

McLEOD, N.

1974: "Ethnomusicological Research and Anthropology," Annual Review of Anthropology, III: 99-115.

McLEOD, N. AND MARCIA HERNDON, eds.

1980: The Ethnography of Musical Performance. Norwood, Penn.: Norwood Editions.

McMULLEN, R.

1968: Art, Affluence, and Alienation. New York: Mentor Books. MERRIAM, A.

1955: "The Use of Music in the Study of a Problem of Acculturation," American Anthropologist, LVII/1, 28-34.

1963: “Melville J. Herskovits, 1895-1963," Ethnomusicology, VII/2, 79-82.

1964: The Anthropology of Music. Evanston: Northwestern University Press.

1967: Ethnomusicology of the Flathead Indians. Chicago: Aldine Publishing Co.

1969: "Ethnomusicology Revisited," Ethnomusicology, XIII/2, 213-29.

1980: Review of African Rhythm and African Sensibility: Aesthetics and Social Action in African Musical Idioms by John M. Chernoff, Ethnomusicology, XXIV/3, 559-61.

NETTL, B.

1954: North American Indian Musical Styles Philadelphia: American Folklore Society.

1956: Music in Primitive Culture. Cambridge: Harvard University Press.

1964: Theory and Method in Ethnomusicology. New York: The Free Press.

1966: "Some Influences of Western Civilization on North American Indian Music," in Browne, R., Winkelman, D., and Haymen, A., eds., New Voices in America. Purdue University Studies, 129-37. 
1978: "Some Aspects of the History of World Music in the Twentieth Century: Questions, Problems, and Concepts," Ethnomusicology, XXII/1, 123-36.

1979: "Paradigms in the History of Ethnomusicology," College Music Symposium, XIX/1, 67-77.

1983: The Study of Ethnomusicology: Twenty-nine Issues and Concepts. Urbana: University of Illinois.

ORLOV, H.

"The Cultural Dimensions of Musical Experience" (Unpublished $\mathrm{ms}$. in the author's possession).

POWERS, W.K.

1980: "Oglala Song Terminology," in Heth (1980), 23-41.

REINHARD, $K$.

1971: "The Berlin Phonogramm-Archiv," in McAllester, D.P., ed., Readings in Ethnomusicology. New York: Johnson Reprint Corp., 17-23.

RHODES, W.

1967: "Acculturation in North American Indian Music" (1952), in Tax, S., ed., Acculturation in the Americas: Proceedings and Selected Papers. New York: Cooper Square Publishers, 127-132

ROBERTS, $\mathrm{H}$.

1936: Musical Areas of Aboriginal North America. Yale University Publications in Anthropology, No. 12.

ROTHSTEIN, E.

1982: "Learning From Man's Varied Musics," The New York Times,

SACHS, C. Sunday, January 10, Section A, p. 21.

1962: The Wellsprings of Music. New York: Da Capo Press.

SAHLINS, $M$.

1976: Culture and Practical Reason. Chicago: University of Chicago Press.

SCHOLTE, $B$.

1978: "On the Ethnocentricity of Scientistic Logic," Dialectical Anthropology, III/2, 177-89.

SEEGER, A.

1979: "What Can We Learn When They Sing?: Vocal Genres of the Suya Indians of Central Brazil," Ethnomusicology, XXIII/3, 373-94.

1980: "Sing For Your Sister: The Structure and Performance of Suya Akia," in McLeod and Herndon (1980: 7-42).

SEEGER, C.

1980: ["Interview with David Dunaway"], Ethnomusicology, XXIV/2, 160-68. 
SHEPHERD, J.

1977: "The Musical Coding of Ideologies," in Shepherd, J., et al., Whose Music? A Sociology of Musical Languages. London: Latimer New Dimensions; reprinted New Brunswick, N.J.: Transaction Books, 1980, 69-124.

SMALL, C.

1977: Music. Society. Education. London: Calder.

SMITHSONIAN INSTITUTION

1979: Opportunities for Research and Study in History, Art, and Science. Washington, D.C.

STUMPF, C.

1886: "Lieder der Bellakula Indianer," Vierteljahrschrift für Musikwissenschaft, II, 405-26.

1892: "Phonographierte Indianermelodien," Vierteljahrschrift für Musikwissenschaft, VIII, 127-44.

1911: Die Anfänge der Musik. Leipzig: J.A. Barth. TEDLOCK, B.

1980: "Songs of the Zuni Kachina Society: Composition, Rehearsal, and Performance," in Frisbie, C., ed., Southwestern Indian Ritual Drama. Albuquerque: University of New Mexico Press, 7-35.

TYLOR, E.

1958: The Origins of Culture [Chapters I-X of Primitive Culture (1871)]. New York: Harper.

VOGET, F.

1975: A History of Ethnology. New York: Holt, Rinehart and Winston.

WACHSMANN, $\mathrm{K}$.

1961: "Criteria for Acculturation," in Report of the Eighth Congress of the International Musicological Society. New York, Vol. 1 (Kassel: Barenreiter-Verlag).

WALLASCHEK, $\mathrm{R}$.

1970: Primitive Music (1893). New York: Da Capo Press. WISHART, TREVOR

1977: "Musical Writing, Musical Speaking," in John Shepherd, et al., Whose Music? A Sociology of Musical Languages. London: Latimer New Dimensions; reprinted New Brunswick, N.J.: Transaction Books 1980, 125-53.

WISSLER, C.

1917: The American Indian. New York: Oxford University Press. WYNTER, S.

1976: "Ethno or Socio Poetics," Alcheringa, new series II/2, 78-94. 